\title{
Rainfall Parameters Affecting Splash Erosion under Natural Conditions
}

\author{
Nives Zambon ${ }^{1, *}$, Lisbeth Lolk Johannsen ${ }^{1}\left(\mathbb{D}\right.$, Peter Strauss ${ }^{2}\left(\mathbb{D}\right.$, Tomas Dostal ${ }^{3}(\mathbb{D}$, \\ David Zumr $^{3}{ }^{1}$, Martin Neumann ${ }^{3}$, Thomas A. Cochrane ${ }^{4} \mathbb{D}$ and Andreas Klik ${ }^{1}$ \\ 1 Institute for Soil Physics and Rural Water Management, University of Natural Resources and Life Sciences, \\ 1190 Vienna, Austria; lisbeth.johannsen@boku.ac.at (L.L.J.); andreas.klik@boku.ac.at (A.K.) \\ 2 Institute for Land and Water Management Research, 3252 Petzenkirchen, Austria; peter.strauss@baw.at \\ 3 Faculty of Civil Engineering, Czech Technical University in Prague, 16629 Prague 6, Czech Republic; \\ dostal@fsv.cvut.cz (T.D.); david.zumr@fsv.cvut.cz (D.Z.); martin.neumann@fsv.cvut.cz (M.N.) \\ 4 Department of Civil and Natural Resources Engineering, University of Canterbury, \\ Christchurch 8140, New Zealand; tom.cochrane@canterbury.ac.nz \\ * Correspondence: nives.zambon@boku.ac.at
}

Received: 28 April 2020; Accepted: 10 June 2020; Published: 15 June 2020

Featured Application: Practical and cost-effective splash cup method for splash erosion measurements in field and laboratory conditions.

\begin{abstract}
The interaction between rainfall erosivity parameters and splash erosion is crucial for describing the soil erosion process; however, it is rarely investigated under natural rainfall conditions. In this study, we conducted splash erosion experiments under natural rainfall on three sites in Central Europe. The main goal was to obtain the relationship between splash erosion of the bare soil in seedbed condition and commonly used rainfall erosivity parameters (kinetic energy, intensity, and rainfall erosivity $\left.\left(E I_{30}\right)\right)$. All sites were equipped with a rain gauge and an optical laser disdrometer where the splash erosion was measured, with modified Morgan splash cups. In order to investigate which parameter best describes the splash erosion process for all sites, a regression analysis was performed. In total, 80 splash erosion events were evaluated. Splash erosion can be described as a linear function of total kinetic energy and a non-linear function of $E I_{30}$. However, the use of the total kinetic energy led to underestimation of the splash erosion rates for highly intensive rainfalls. Therefore, better results were obtained when using average rainfall intensity as the splash erosion predictor or the kinetic energy divided by the rainfall duration. Minor differences between the replicates during splash erosion measurements indicate that the modified Morgan splash cup provides a good tool for soil erosion assessment.
\end{abstract}

Keywords: splash erosion; splash cup; kinetic energy; rainfall intensity; rainfall erosivity

\section{Introduction}

Soil erosion by water is the most common soil degradation process globally, and in arable cropland it is consistently higher than soil formation [1]. Detailed knowledge of the processes that control erosion on arable croplands contributes to better application of soil management techniques that minimize and control soil erosion risk [2]. Splash erosion starts with the raindrop impact on the soil surface, which represents the first stage in soil erosion by water [3]. The detached soil particles transported by raindrop impact are deposited on the near-distance soil surface or are transported further by surface runoff if the infiltration capacity of the soil is reached [4]. The major splash erosion driver is the erosivity of rainfall, which can be expressed by parameters like rainfall intensity [5-7], kinetic energy (KE) [8-10], rainfall 
erosivity $\left(E I_{30}\right)$ [11], or raindrop momentum [12]. Apart from the rainfall properties, the detachment of soil particles also depends on soil physico-chemical characteristics, such as infiltration capacity $[13,14]$, initial water content $[15,16]$, the ability to form stable aggregates and crusts $[17,18]$, organic matter content [19], texture, cohesion, porosity, capacity of ionic interchange, and clay content [20].

Splash erosion measurements on a small scale are usually done through splash cups or splash containers [21-26]. Most of the splash erosion studies have been conducted in the laboratories using rainfall simulators, where by controlling the raindrop size and fall height, the $K E$ of raindrops is adjusted [12,27-30]. However, rainfall simulators often do not reproduce the same rainfall drop size and velocity distribution characteristics as in nature [31]. As the velocity of raindrops is controlled by the height at which the nozzles are located, due to space or design limitations, sometimes raindrops cannot reach the terminal velocity of natural raindrops [32]. By applying different pressure at the nozzle, the raindrop velocity can be adjusted regarding to the raindrop size; however, large drops are unlikely to reach their terminal velocity, and consequently the $K E$, of natural rainfall [33]. Nevertheless, laboratory experiments improve the consistency of the results by minimizing the effects of the various uncontrolled factors that are present in the field [34], and also allow experiments to be repeated.

Splash erosion experiments under natural rainfall investigate the relationship between rainfall erosivity and splash detachment [3]. Morgan [23] observed the splash erosion under natural rainfall for 100 consecutive days, comparing four different soil textures. The KE of rainfall was calculated from the $10 \mathrm{~min}$ rainfall intensity values, using the formula from Hudson [35]. Splash erosion of the bare soil was significantly correlated with KE. Govers [36] collected data at 21 sites in Belgium using circular splash cups. He found that the product of rainfall $K E$ and drop circumference are better at expressing the rainfall erosivity compared to $K E$ and intensity, or when the 0.75 power of rainfall intensity is used. However, a detailed drop size distribution (DSD) was not available at the time, and the fall velocities of raindrops were based on data by Laws [37]. Splash erosion under natural conditions is primarily affected by rainfall DSD. The ability of raindrop impact to cause splash erosion (rainfall erosivity) is mainly dependent on drop size and drop fall velocity [12]. Direct measurements of raindrop size and velocity provide precise information about the erosivity of rainstorms-namely, $K E$. When the raindrop size and velocity is not directly measured, the rainfall $K E$ is estimated from the experimentally based equations between rainfall intensity and $K E$ from other studies. Theoretically obtained rainfall $K E$ could underestimate or overestimate the real KE [38-40]. Furthermore, DSD obtained from other studies can significantly vary depending on rain type and geographical location [41]. With the development of optical laser techniques (disdrometer), the continuous and direct measurement of raindrop size and velocity has become easily available to assess rainfall $\mathrm{KE}$.

A recent study with splash erosion measurements under natural rainfall, using the splash cup technique and rainfall monitoring with a disdrometer, was performed by Fernández-Raga et al. [42]. They used a funnel and cup installed directly in the field for splash erosion measurements, and found a good correlation between splash erosion and rainfall $K E$; however, their findings were based on only nine sampling periods. Angulo-Martínez et al. [43] conducted a study in Spain where the splash erosion of three soil types was measured with Morgan splash cups [23]. A significant relationship was found between splash erosion and the rainfall erosivity index $E I_{30}$, and high variabilities between the replicates indicated the heterogeneity in splash erosion spatial distribution. According to the results reported from these studies, there are still many uncertainties concerning the changes in surface condition and spatial distribution of splash erosion.

The studies investigating splash erosion under natural rainfall are limited to local conditions. Consequently, monitoring of the rainfall characteristics on higher temporal and spatial resolution is crucial for describing the dominant rainfall parameters on splash erosion related to a specific location. Apart from the field studies of Fernández-Raga et al. [42] and Angulo-Martínez et al. [43], there are very few experiments that include both the monitoring of splash erosion and rainfall characteristics, including DSD, in the same location. Considering the local influences and lack of the data sets on rainfall DSD, it is difficult to define the role of splash in soil erosion process and predict it relative to 
local conditions. Furthermore, Bauer [44] pointed out that many rain events in Central Europe do not generate overland flow, but splash erosion is initiated already from the first drop impact, which emphasizes the importance of this soil degradation process. Lack of knowledge about the effect of erosive rainfall events on splash detachment in the agriculturally active Central European area was the main motivation for the present study.

This study presents the results from the splash erosion measurements collected during three consecutive summer seasons at three sites in Central Europe. Together with splash erosion, rainfall parameters, including rainfall intensity and $K E$, were monitored at the sites, with the aim of analyzing performance of the most common rainfall erosivity parameters (KE, intensity, and rainfall erosivity $\left.\left(E I_{30}\right)\right)$, in order to predict splash erosion under natural rainfall.

\section{Materials and Methods}

\subsection{Study Sites}

The monitoring of rainfall parameters and splash erosion measurements was located at two sites in Austria and one in the Czech Republic (Figure 1). The Austrian sites, Petzenkirchen $\left(48^{\circ} 9^{\prime} 17^{\prime \prime} \mathrm{N}\right.$, $15^{\circ} 14^{\prime} 46^{\prime \prime}$ E) and Mistelbach ( $48^{\circ} 34^{\prime} 59^{\prime \prime}$ N, $16^{\circ} 35^{\prime} 15^{\prime \prime}$ E), are situated in the region of Lower Austria, where most of the country agricultural activity takes place. The Czech site was located in Prague $\left(50^{\circ} 6^{\prime} 17^{\prime \prime} \mathrm{N}, 14^{\circ} 23^{\prime} 15^{\prime \prime} \mathrm{E}\right)$. The long-term, average annual precipitation for the three sites is 902,537 and $459 \mathrm{~mm}$ for Petzenkirchen, Mistelbach, and Prague, respectively [45-47]. According to data measured by Klik and Truman [48] in Lower Austria, most of the erosive storms occurred during the summer period. Panagos et al. [49] also confirmed the highest rainfall erosivity during summer in the Central European region. Therefore, the selected monitoring period was during late spring and summer from 2017 to 2019.

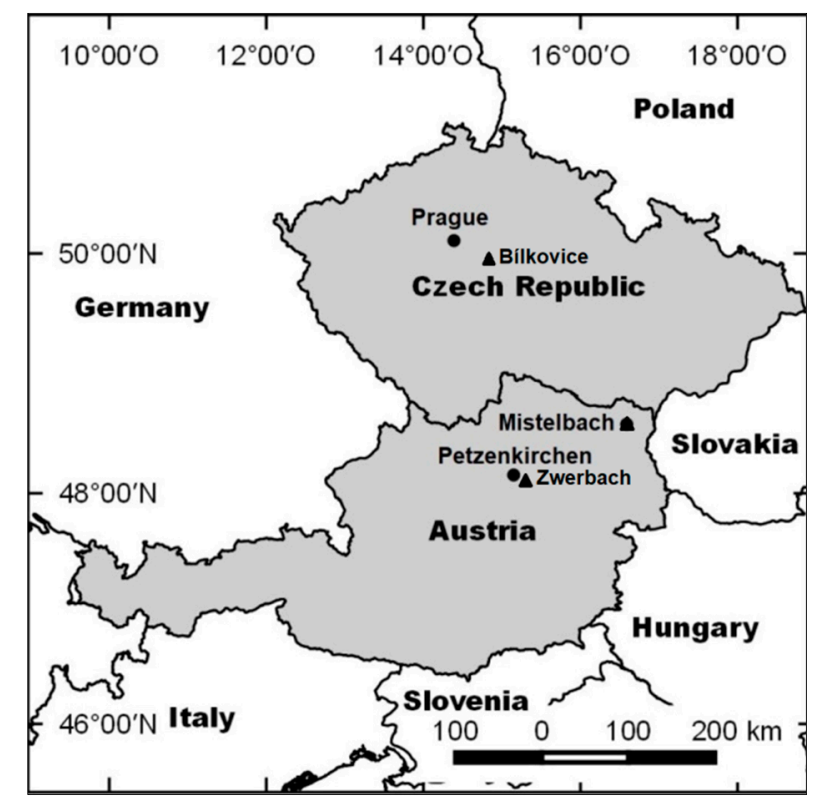

Figure 1. Location map of the study sites in Austria (Petzenkirchen and Mistelbach) and the Czech Republic (Prague), marked with solid dots, and locations of the soil sampling sites (Zwerbach, Mistelbach and Bílkovice), marked with solid triangles. 


\subsection{Investigated Soils}

Soil samples were taken from two locations in Austria close to the experimental sites, Zwerbach (ZW) $\left(48^{\circ} 8^{\prime} 22^{\prime \prime} N, 15^{\circ} 14^{\prime} 46^{\prime \prime}\right.$ E) and Mistelbach (MI) (48 $35^{\prime} 3^{\prime \prime} \mathrm{N}, 16^{\circ} 35^{\prime} 16^{\prime \prime}$ E). In the Czech Republic, soil samples were taken within the Central Bohemian Region in Bílkovice (BK) $\left(49^{\circ} 45^{\prime} 41.5^{\prime \prime} \mathrm{N}\right.$, $\left.14^{\circ} 50^{\prime} 20.0^{\prime \prime} \mathrm{E}\right)$. The locations of three sites are marked in Figure 1. The samples were collected from agricultural land in the first $10 \mathrm{~cm}$ during April 2017, after seedbed preparation. Soil was dried and sieved through a $10 \mathrm{~mm}$ sieve and distributed to the three experimental sites. Particle size distribution was determined with a combined wet sieving and sedimentation method, as defined in the Austrian Norm for soil physical analysis [50,51]. Accordingly, soil textures were determined using the Austrian soil texture triangle [52]. Soil $\mathrm{pH}$ was obtained with electrometric $\mathrm{pH}$ meter. Total organic carbon was measured according to the Austrian Norm for the determination of soil organic carbon [53], and the aggregate stability of soils was determined with the modified Kemper and Rosenau method [54]. The physical and chemical properties of the soils obtained in the laboratory analysis are listed in Table 1.

Table 1. Soil physical and chemical properties.

\begin{tabular}{cccccccc}
\hline Soil & Sand [\%] & Silt [\%] & Clay [\%] & Soil Texture & AS [\%] & pH & TOC [\%] \\
\hline Zwerbach & 14.0 & 60.2 & 25.8 & Silt loam & 41.4 & 7.5 & 1.5 \\
Mistelbach & 11.2 & 70.4 & 18.4 & Silt loam & 18.3 & 8.2 & 1.6 \\
Bílkovice & 41.6 & 46.3 & 12.1 & Loamy sand & 63.3 & 6.9 & 1.7 \\
\hline \multicolumn{7}{c}{ Notes: AS = aggregate stability; TOC = total organic carbon. }
\end{tabular}

\subsection{Splash Erosion Measurements}

Splash erosion was measured with the splash cup technique proposed by Morgan [23]. The splash cup was produced from a light polypropylene material, with an inner diameter of $10.3 \mathrm{~cm}$ and a standing height of $6 \mathrm{~cm}$. On the bottom of the splash cup, holes were drilled to ensure water drainage through the soil; however, two fine meshes $(500$ and $1000 \mu \mathrm{m})$ were placed on the bottom to prevent soil loss trough the holes (Figure 2a). Air-dried and sieved soil $(<10 \mathrm{~mm})$ was filled in three layers up to $1 \mathrm{~cm}$ below the splash cup edge, to prevent the overflow of soil on the surface during the high intensity rainfall. While levelling it continuously using a long needle, each soil layer was slightly compacted to reach similar conditions (bulk density) as in the field. Aggregates at the top layer surface were randomly distributed to achieve heterogeneous arrangement. For each soil, more or less the same mass was filled into the splash cups, to keep soil density (in seedbed condition) constant within the replicates (Figure 2b). Major differences in the soil structure of the samples prepared for experiment and the original soil in seedbed condition are the aggregate size and their arrangement, due to sieving and sample preparation. However, soil bulk density and porosity were within the same range of the soil in the seedbed condition in the field. Splash cups filled with soils were placed in the middle of a splash collector, with standing height of $30 \mathrm{~cm}$ and diameter of $47 \mathrm{~cm}$ (Figure 2c). The splash collector had an outlet, ensuring the drainage of rainfall water with splashed soil into collectors placed underneath (Figure 2d). The water collector underneath was completely closed, ensuring that only splashed soil was trapped into the collector. Splash cups were installed in the field in such a way that the soil surface was $1 \mathrm{~m}$ above ground level, which corresponds to the same height as the disdrometer (described in next chapter). A detailed splash cup and splash collector design can be found in Zumr et al. [55]. 

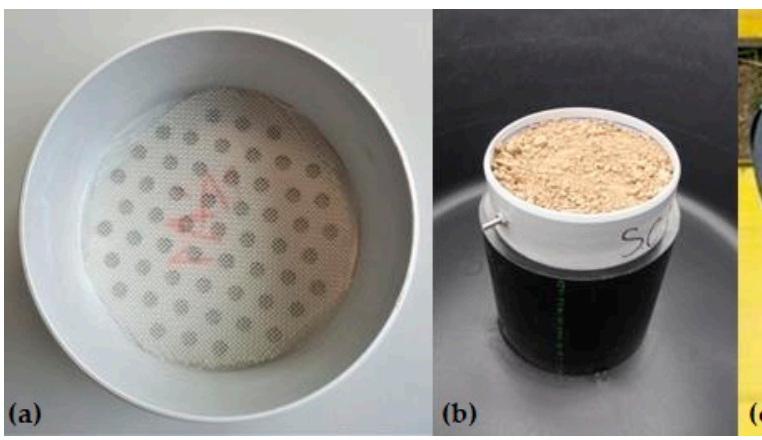

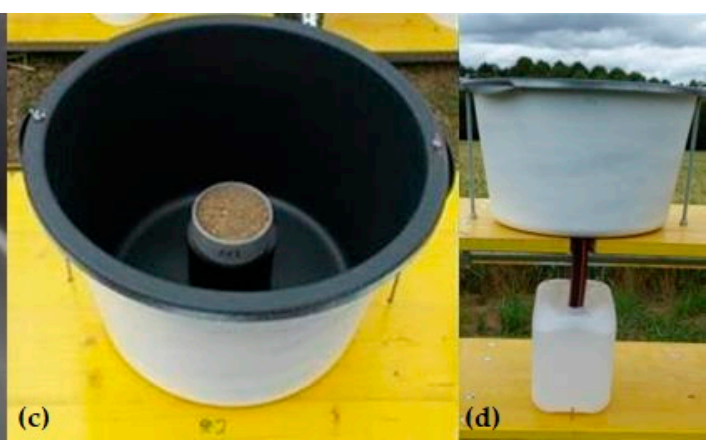

Figure 2. Experimental set-up for splash erosion measurements: (a) splash cup with mesh at the bottom; (b) splash cup filled with soil; (c) splash collector; and (d) connection with drainage pipe to water and soil collector.

Splash cups were exchanged, and splashed sediment was collected after each rainfall event, with accumulated precipitation of $5 \mathrm{~mm}$. The events with precipitation lower than $5 \mathrm{~mm}$ were considered as erosive if the accumulated rainfall of $2.5 \mathrm{~mm}$ was reached after $15 \mathrm{~min}$. This threshold was adopted based on preliminary data analysis and recommended by some European authors $[44,56]$. The intensity threshold of $12.7 \mathrm{~mm}$ ( 0.5 in), reported in the Revised Universal Soil Erosion Equation (RUSLE) [11], is too high for European conditions. A rainfall event was defined as the rain period separated between proceeding and succeeding rainfall by $6 \mathrm{~h}$ or more. The splashed soil particles on the rim of the splash collector were completely washed off and drained into the water collector with rainfall and sediment. In the laboratory, splashed particles were filtered from water and oven-dried at $40{ }^{\circ} \mathrm{C}$. The average mass of the splashed soil per each rainfall event was calculated from the three or four replicates, depending on the study site.

\subsection{Rainfall Parameters}

At all sites, rainfall data were collected with a rain gauge (tipping bucket or balance principle). To obtain the KE of rainfall, each site was equipped with an optical laser disdrometer, which measures raindrop size and velocity distribution in one-minute intervals. The PWS100 Present Weather Sensors from Campbell Scientific (PWS100) were installed in Mistelbach and Petzenkirchen, and the Laser Precipitation Monitor from Thies Clima (Thies) in Prague. The devices differ in measurement principle, sampling area, and drop size and velocity distribution classes. The PWS100 sampling area was $40 \mathrm{~cm}^{2}$, in which the drops are categorized in 34 size and 34 velocity classes. The Thies had a sampling area of $44.1 \mathrm{~cm}^{2}$, with 22 drop sizes and 20 velocity classes. Both disdrometer types differentiate raindrops from hail, ice pellets, and graupel. A detailed description of the disdrometer and rainfall monitoring set-ups at the three sites is given in Johannsen et al. [57].

The rainfall kinetic energy per area, $K E\left(\mathrm{~J} \mathrm{~m}^{-2}\right)$, was calculated for the diameter class $i$ and velocity class $j$ that are provided by the disdrometer, as follows:

$$
K E=\sum N_{i, j} \cdot \frac{1}{12 \cdot A} \cdot \pi \cdot 10^{-6} \cdot \rho \cdot D_{i}^{3} \cdot v_{j}^{2},
$$

where $N_{i, j}$ is number of detected raindrops of a certain size class $i$ and velocity class $j ; A$ is the sampling area of the disdrometer $\left(\mathrm{m}^{2}\right) ; \rho$ is density of water $\left(\mathrm{g} \mathrm{cm}^{-3}\right) ; D_{i}$ is mean drop diameter $(\mathrm{mm})$ of size class $i$; and $v_{j}$ is mean fall velocity $\left(\mathrm{m} \mathrm{s}^{-1}\right)$ of velocity class $j$. The mass of the raindrop is calculated assuming a spherical drop shape. Total $K E$ is the sum of kinetic energies for each drop size and velocity, multiplied by the number of drops in the corresponding classes. Cumulative $K E$ of a single rainfall event, $K E_{\text {sum }}\left(\mathrm{J} \mathrm{m}^{-2}\right)$, was defined as

$$
K E_{\text {sum }}=\sum_{i=1}^{n} K E_{i}
$$


where $K E_{i}$ represents the $i$-th minute of the rainfall event. The $K E$ per rainfall duration was calculated as

$$
K E_{h}=\frac{K E_{\text {sum }}}{T}
$$

where the $K E_{h}$ is kinetic energy per hour $\left(\mathrm{J} \mathrm{m}^{-2} \mathrm{~h}^{-1}\right)$ and $T$ is total duration of a rainfall event $(\mathrm{h})$, measured from the beginning of rainfall.

The results obtained in the recent study by Johannsen et al. [57] showed that the differences in rainfall measurements from different disdrometer types, including PWS100 and Thies, influenced the interpretation of rainfall KE. That study concluded that the Thies disdrometer measured higher numbers of smaller drops; therefore, it underestimated the rainfall $K E$. To ensure comparable results obtained from the two disdrometer types used in this study, we applied the suggested correction factor by Johannsen et al. [57] for the Thies disdrometer. The correction is the ratio of the slope factors obtained from the KE and the intensity relationships for the PWS100 and Thies disdrometers. Accordingly, the final $K E$ for the Thies disdrometer is calculated as in Equation (2) and multiplied with a correction factor of 1.36 .

For the periods when the disdrometer data were not available due to disruptions or errors, the $K E$ was calculated based on $K E$ and intensity relationships developed for the three sites, according to the data investigated in Johannsen et al. [40]. The $K E$ is presented as the function of the intensity, which was available from the rain gauge.

The average rainfall intensity $I_{a v}\left(\mathrm{~mm} \mathrm{~h}^{-1}\right)$ of single rainfall event considered the amount of rainfall over a time period, and is expressed as

$$
I_{a v}=\frac{P}{T}
$$

where $P$ is the cumulative rainfall precipitation $(\mathrm{mm})$ over rainfall duration $T(\mathrm{~h})$.

The rainfall erosivity $E I_{30}\left(\mathrm{MJ} \mathrm{mm} \mathrm{ha} \mathrm{m}^{-1} \mathrm{~h}^{-1}\right)$ [11] for soil erosion estimation was also considered in analysis as an important rainfall parameter affecting splash erosion. The erosivity of a single rainfall event has been defined by the following expression:

$$
E I_{30}=K E_{\text {sum }} \cdot 100 \cdot I_{30}
$$

where $I_{30}$ is the maximum 30 min rainfall intensity of one rainfall event $\left(\mathrm{mm} \mathrm{h}^{-1}\right)$.

Rainfall erosivity density expresses the mean rainfall erosivity per rainfall unit [49]. The mean monthly erosivity density $M E D\left(\mathrm{MJ} \mathrm{ha}^{-1} \mathrm{~h}^{-1}\right)$ is expressed as:

$$
M E D=\frac{1}{n} \cdot \sum_{i=0}^{n}\left(\frac{E I_{30}}{P}\right)_{i}
$$

where $n$ is the number of rainfall events (i) recorded during one month. The total splash erosion rate per one measurement period was calculated as the total amount of the splashed material from the test area per unit area, which is calculated as follows:

$$
S=\frac{m_{S}}{A_{s}}
$$

where $S$ is average splash erosion rate $\left(\mathrm{g} \mathrm{m}^{-2}\right), m_{S}$ is the mass of splashed material, and $A_{s}$ is the area of the splash cup $\left(0.0084 \mathrm{~m}^{2}\right)$. Splash erosion $S_{h}\left(\mathrm{~g} \mathrm{~m}^{-2} \mathrm{~h}^{-1}\right)$ per rainfall event duration $(T)$ was calculated as

$$
S_{h}=\frac{S}{T}
$$




\subsection{Data Analysis}

The coefficient of determination $\left(R^{2}\right)$ and the root mean square error (RMSE) were used to validate the efficiency of the influencing rainfall erosivity parameters as the predictors of splash erosion. Pearson correlation analysis was used to estimate the relationship between the splash erosion rates and the sand, silt, or clay content of the three soils. The Kruskal-Wallis [58] test by ranks was used to determinate the differences in splash rates between the three soils.

\section{Results}

\subsection{Rainfall Data}

During the splash erosion measurements, the rainiest months were May 2019 in Petzenkirchen, July 2018 in Mistelbach, and June 2018 in Prague (Figure 3). The Mistelbach site had the highest cumulative $E I_{30}$ of $4168 \mathrm{MJ} \mathrm{mm} \mathrm{ha}{ }^{-1} \mathrm{~h}^{-1}$; however, the highest monthly $E I_{30}$ of $1352 \mathrm{MJ} \mathrm{mm} \mathrm{ha}^{-1} \mathrm{~h}^{-1}$ was recorded at the Prague site during June 2018.
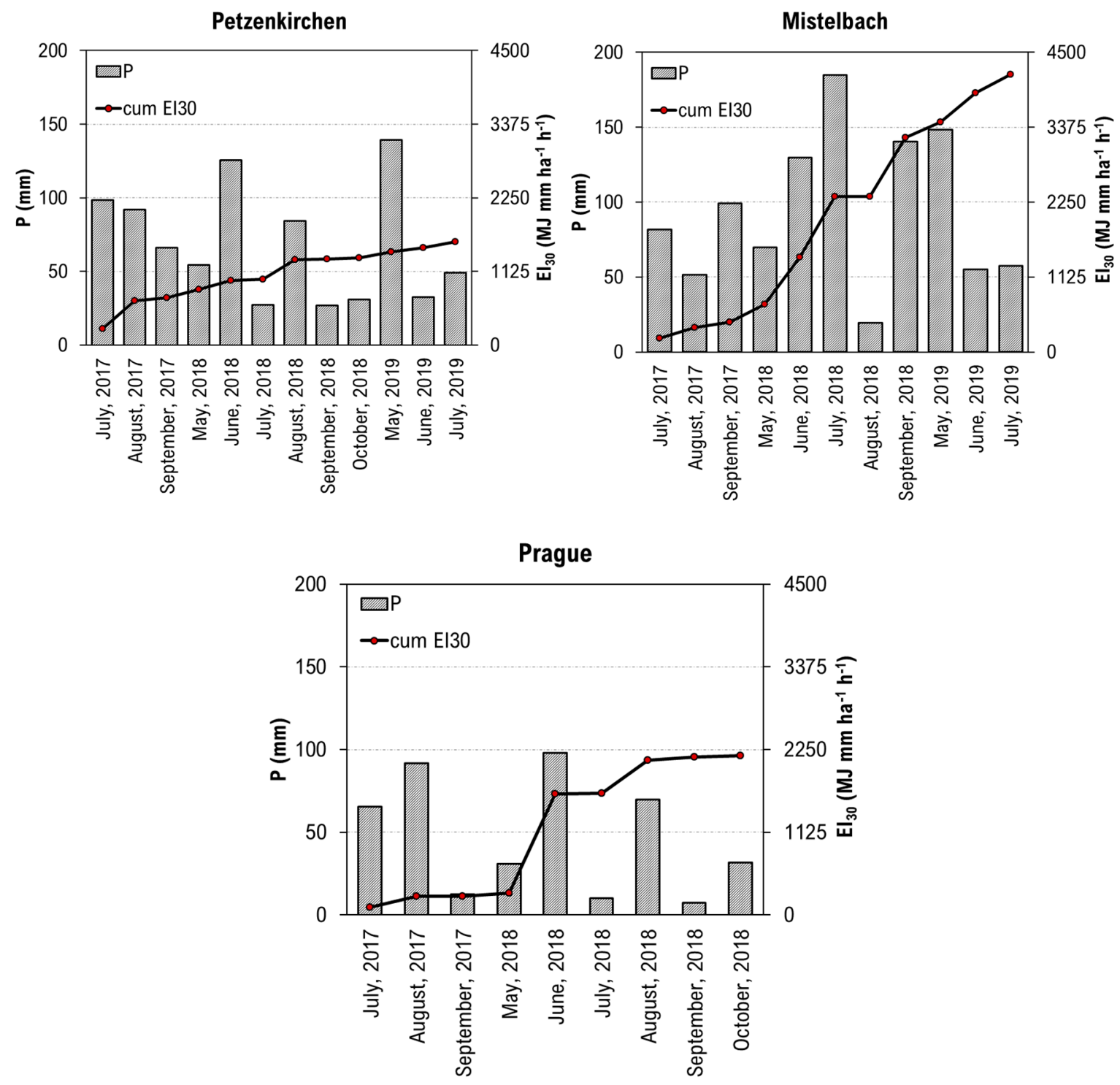

Figure 3. Accumulated monthly rainfall precipitation $P(\mathrm{~mm})$ and cumulative rainfall erosivity $E I_{30}$ $\left(\mathrm{MJ} \mathrm{mm} \mathrm{ha} \mathrm{m}^{-2} \mathrm{~h}^{-1}\right.$ ) distribution for investigated sites during the measuring period. 
During the measuring period, the Mistelbach site had highest average monthly rainfall, $K E, E I_{30}$, and erosivity density, as well as the largest mean drop diameter (Table 2). Petzenkirchen was the site with the noticeably lowest average monthly $E I_{30}$ and erosivity density. The Prague site had lowest monthly precipitation among the three sites. However, higher average monthly $E I_{30}$ and erosivity density compared to the Petzenkirchen site were caused by intensive storms recorded in June and August 2018 (Figure 3). It should be noted that calculated mean drop diameter could be affected by differences in measured drop size distributions between the disdrometer types used in the study [40].

Table 2. Average monthly rainfall parameters measured at the three study sites.

\begin{tabular}{cccc}
\hline & \multicolumn{3}{c}{ Study Sites } \\
\cline { 2 - 4 } & Petzenkirchen & Mistelbach & Prague \\
\hline Number of months measured & 12 & 11 & 9 \\
Precipitation $(\mathrm{mm})$ & 68.7 & 94.0 & 46.5 \\
Kinetic energy $\left(\mathrm{J} \mathrm{m}^{-2}\right)$ & 1026.0 & 1876.9 & 661.7 \\
Rainfall erosivity $\left(\mathrm{MJ} \mathrm{mm} \mathrm{ha} \mathrm{mm}^{-1} \mathrm{~h}^{-1}\right)$ & 131.6 & 378.9 & 241.0 \\
Erosivity density $\left(\mathrm{MJ} \mathrm{ha}^{-1} \mathrm{~h}^{-1}\right)$ & 1.7 & 3.8 & 3.6 \\
Raindrop diameter $\left(\mathrm{mm}^{*}\right.$ & 0.9 & 1.2 & 0.6 \\
\hline
\end{tabular}

* According to Johannsen et al. [40].

\subsection{Splash Erosion as the Function of Total Kinetic Energy}

During the measuring period, 99 splash erosion records of the three soils were obtained from the investigated sites. After the data evaluation, a total of 80 records that had complete rainfall and splash erosion measurements were selected for further data analysis.

For measured $K E_{\text {sum }}$, the mean splash erosion rates ranged between 4 and $2503 \mathrm{~g} \mathrm{~m}^{-2}$ for $\mathrm{ZW}, 5$ to $1972 \mathrm{~g} \mathrm{~m}^{-2}$ for MI, and 12 to $2508 \mathrm{~g} \mathrm{~m}^{-2}$ for BK soils (Figure 4). The variabilities between the splash erosion replicates were larger for the measurements of $K E_{\text {sum }}$ above $780 \mathrm{~J} \mathrm{~m}^{-2}$.

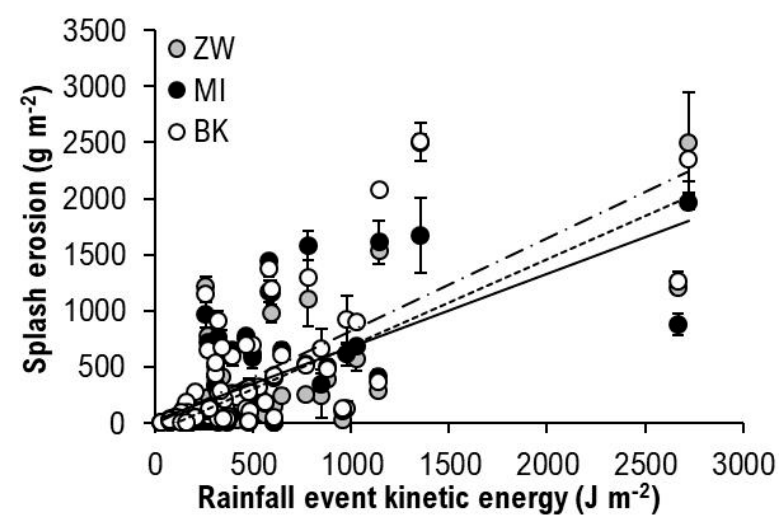

Figure 4. Mean splash erosion for Zwerbach (ZW), Mistelbach (MI), and Bílkovice (BK) soil versus rainfall event cumulative kinetic energy. The dashed-dotted line represents the fitted linear regression line for BK soil, while the dashed line represents $\mathrm{ZW}$, and the solid line represents MI.

Significant $(p<0.05)$ linear regression was obtained for the three soils, as the splash erosion for each soil was positively correlated to $K E_{\text {sum }}$ with $R^{2}$ of $0.52,0.50$, and 0.45 for the BK, ZW, and MI soils, respectively (Table 3). According to the linear model, BK soil yielded the highest splash erosion, followed by ZW and MI soils. RMSE indicated a high deviation of measured values and values predicted by linear relationships. 
Table 3. Main outputs of the regression analysis between splash erosion $S\left(\mathrm{~g} \mathrm{~m}^{-2}\right)$ for Zwerbach (ZW), Mistelbach (MI), and Bílkovice (BK) soils and rainfall event cumulative kinetic energy $K E_{\text {sum }}\left(\mathrm{J} \mathrm{m}^{-2}\right)$. $R^{2}$ is the determination coefficient of the regression model, and RMSE $\left(\mathrm{g} \mathrm{m}^{-2}\right)$ indicates the root mean squared error.

\begin{tabular}{ccccc}
\hline Parameter & Soil & Equation & $\boldsymbol{R}^{\mathbf{2}}$ & RMSE \\
\hline \multirow{3}{*}{$K E_{\text {sum }}$} & ZW & $S=0.767 \cdot K E_{\text {sum }}-75.968$ & 0.50 & 349.25 \\
& MI & $S=0.653 \cdot K E_{\text {sum }}+22.841$ & 0.45 & 326.10 \\
& BK & $S=0.825 \cdot K E_{\text {sum }}-1.299$ & 0.52 & 357.73 \\
\hline
\end{tabular}

\subsection{Impact of Rainfall Intensity on Splash Erosion}

The points deviating above the fitted linear regression line for the BK soil were mostly measured in Mistelbach (Figure 4). Considering the site-specific differences (Table 2), it was necessary to distinguish the erosive events with higher rainfall intensities from the ones with low intensities having the same $K E_{\text {sum }}$. The example in Figure 5 shows two rainfall events with similar cumulative precipitation and $K E_{\text {sum }}$ measured in Mistelbach (Event 1) and Prague (Event 2) with the corresponding splash erosion. The rainfall Event 1 was recorded on June 6, 2018, with a duration of $3.5 \mathrm{~h}$. The rainfall Event 2 was recorded on August 8, 2018, with a duration of $43 \mathrm{~min}$. Cumulative rainfall reached 19 and $20 \mathrm{~mm}$ for Event 1 and Event 2, respectively. Corresponding $K E_{\text {sum }}$ values were $467 \mathrm{~J} \mathrm{~m}^{-2}$ for Event 1 and $446 \mathrm{~J} \mathrm{~m}^{-2}$ for Event 2. However, during Event 2, up to $86 \%$ higher splash erosion rates were measured. Therefore, to compare the effect of kinetic energies characterized by different rainfall intensities on splash erosion, the $K E_{\text {sum }}$ was divided by rainfall duration $(T)$ (defined in Equation (3)).
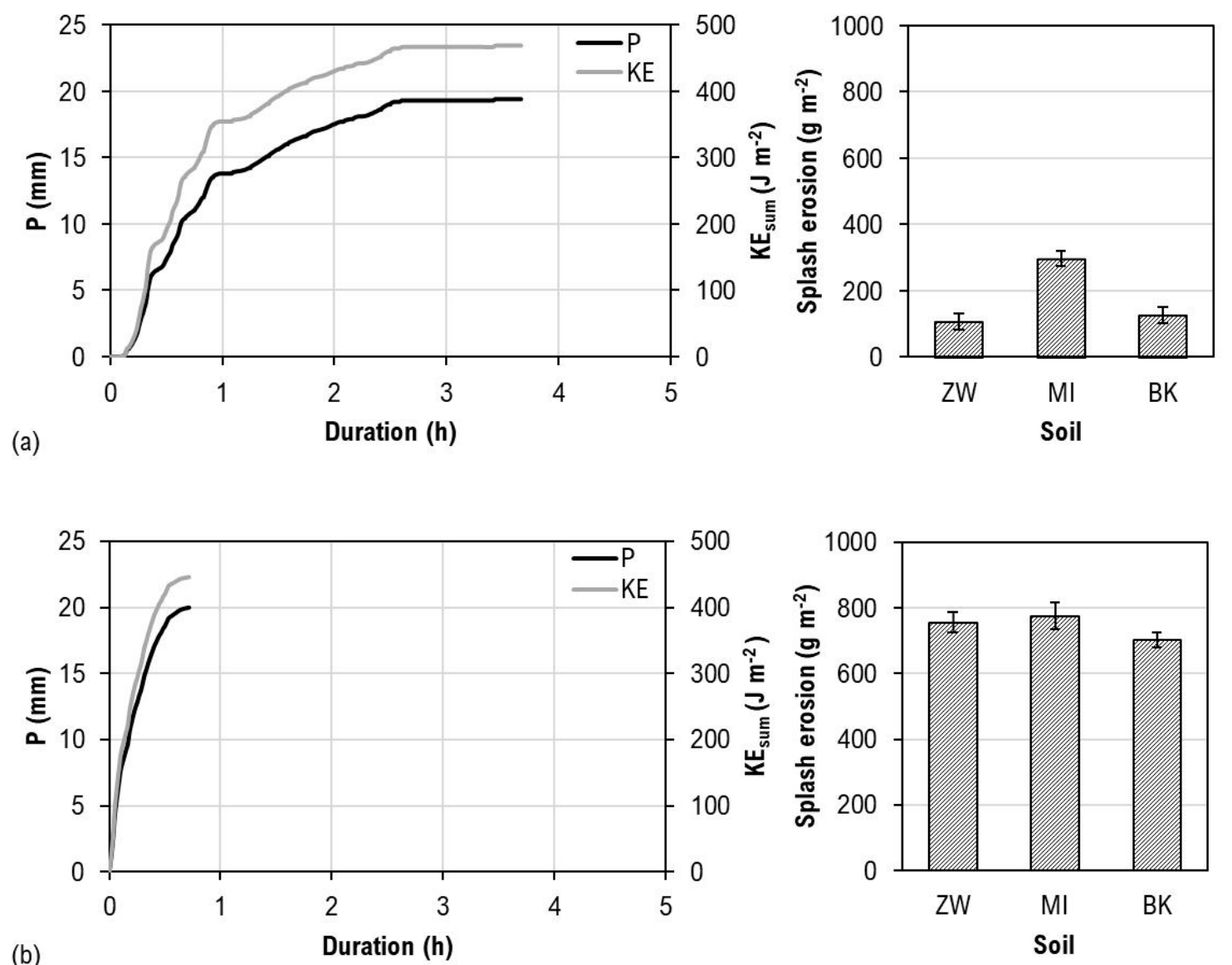

Figure 5. Cumulative rainfall $P(\mathrm{~mm})$ and kinetic energy $K E_{\text {sum }}\left(\mathrm{J} \mathrm{m}^{-2}\right)$ with corresponding mean splash erosion for Zwerbach (ZW), Mistelbach (MI), and Bílkovice (BK) soil for (a) Event 1 and (b) Event 2. 


\subsection{Regression Analysis of Rainfall Erosivity Parameters with Splash Erosion}

Previous results have indicated that the $K E_{\text {sum }}$ could not represent the realistic ability of rainfall to produce splash erosion. Since rainfall intensity plays an important role in rainfall erosivity, together with $I_{a v}$ and $E I_{30}$ the results of regression analysis with $K E_{h}$ are presented in the following section. $K E_{h}$ represents the average energy load per rainfall duration.

\subsubsection{Splash Erosion and Kinetic Energy Per Rainfall Duration}

The relationship between $K E_{h}$ and splash erosion resulted in a non-linear (power) regression function, with an $R^{2}$ of 0.75 for MI soil and 0.76 for ZW and BK soil (Figure 6a, Table 4). The results indicated a less scattered distribution compared to results for $K E_{\text {sum }}$ (Figure 4). However, several observations in Figure 6a present a difference of $97 \%$ between the lowest and the highest splash erosion rate for a similar range of $K E_{h}\left(220-280 \mathrm{~J} \mathrm{~m}^{-2} \mathrm{~h}^{-1}\right)$. The splash erosion measurement with $K E_{h}$ of $220 \mathrm{~J} \mathrm{~m}^{-2} \mathrm{~h}^{-1}\left(E_{1}\right.$ on Figure $\left.6 \mathrm{a}\right)$ was the result of a rainfall event with short duration. Peak intensity of $42 \mathrm{~mm} \mathrm{~h}^{-1}$ was reached at the beginning of a rainfall event, with a short duration of $3 \mathrm{~min}$. This might indicate that the peak intensity duration was too short to produce higher splash erosion rates. High splash erosion rates up to $1044 \mathrm{~g} \mathrm{~m}^{-2} \mathrm{~h}^{-1}$ were measured for the rainfall event with a $K E_{h}$ of $223 \mathrm{~J} \mathrm{~m}^{-2} \mathrm{~h}^{-1}\left(\mathrm{E}_{2}\right)$. Maximum intensity for this rainfall event reached $60 \mathrm{~mm} \mathrm{~h}^{-1}$, where a high percentage of large drops (drop diameter $>3 \mathrm{~mm}$ ) with high velocities $\left(>6 \mathrm{~m} \mathrm{~s}^{-1}\right)$ was measured. The splash erosion rates for the event with $K E_{h}$ of $280 \mathrm{~J} \mathrm{~m}^{-2} \mathrm{~h}^{-1}$ (Figure 6a, $\mathrm{E}_{3}$ ) were remarkably low considering a high amount of the total rainfall of $44 \mathrm{~mm}$.
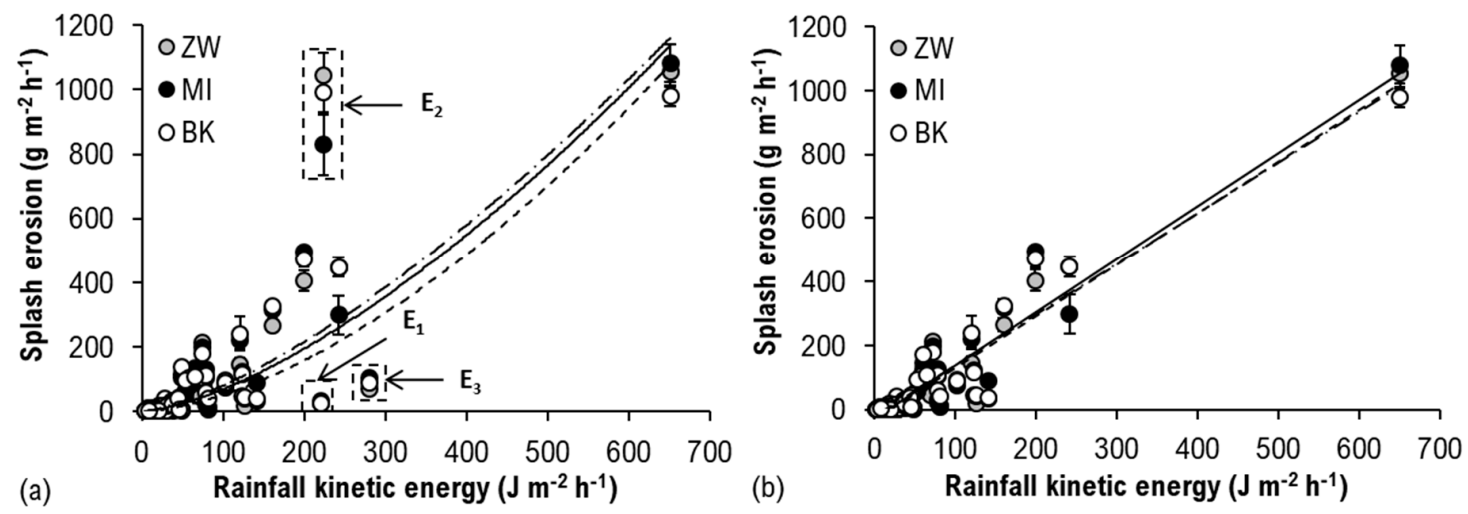

Figure 6. Mean splash erosion for Zwerbach (ZW), Mistelbach (MI) and Bílkovice (BK) soil versus kinetic energy per time unit, including (a) all observations $(n=80)$ and $(\mathbf{b})$ without extreme observations $(n=77)$. The dashed line represents the regression function for $\mathrm{ZW}$, as does the solid line for MI and the dashed-dotted line for BK soil. The points inside the dashed boxes indicate extreme observations $\left(\mathrm{E}_{1}, \mathrm{E}_{2}\right.$, and $\left.\mathrm{E}_{3}\right)$ per soil.

Table 4. Main outputs of the regression analysis between splash erosion $S_{h}\left(\mathrm{~g} \mathrm{~m}^{-2} \mathrm{~h}^{-1}\right)$ for Zwerbach $(\mathrm{ZW})$, Mistelbach (MI), and Bílkovice (BK) soil and rainfall kinetic energy per time unit $K E_{h}\left(\mathrm{~J} \mathrm{~m}^{-2} \mathrm{~h}^{-1}\right)$. The $R^{2}$ is the determination coefficient of the regression model, and RMSE $\left(\mathrm{g} \mathrm{m}^{-2} \mathrm{~h}^{-1}\right)$ indicates the root mean squared error. $E_{1}, E_{2}$, and $E_{3}$ denote extreme observations.

\begin{tabular}{ccccc}
\hline Parameter & Soil & Equation & $\mathbf{R}^{2}$ & RMSE \\
\hline \multirow{2}{*}{$K E_{h}$ (including $\left.\mathrm{E}_{1}, \mathrm{E}_{2}, \mathrm{E}_{3}\right)$} & $\mathrm{ZW}$ & $S_{h}=0.028 \cdot K E_{h}{ }^{1.629}$ & 0.76 & 112.21 \\
& $\mathrm{MI}$ & $S_{h}=0.069 \cdot K E_{h}{ }^{1.498}$ & 0.75 & 91.30 \\
& $\mathrm{BK}$ & $S_{h}=0.113 \cdot K E_{h}{ }^{1.426}$ & 0.76 & 106.27 \\
\hline \multirow{2}{*}{$K E_{h}\left(\right.$ excluding $\left.\mathrm{E}_{1}, \mathrm{E}_{2}, \mathrm{E}_{3}\right)$} & $\mathrm{ZW}$ & $S_{h}=1.621 \cdot K E_{h}-32.289$ & 0.91 & 43.04 \\
& $\mathrm{MI}$ & $S_{h}=1.668 \cdot K E_{h}-27.828$ & 0.91 & 43.40 \\
& $\mathrm{BK}$ & $S_{h}=1.590 \cdot K E_{h}-20.586$ & 0.90 & 43.10 \\
\hline
\end{tabular}


Excluding these observations from the regression analysis, the resulting relationship between splash erosion and $K E_{h}$ was linear, with $R^{2}$ values of 0.91 for $\mathrm{ZW}$ and MI soil, and 0.90 for BK soil (Figure $6 \mathrm{~b}$; Table 4 ). The difference of $62 \%$ between the RMSEs for linear and nonlinear models indicates better performance of the splash erosion- $K E_{h}$ relationship without extreme observations. According to RMSE, correlation coefficients, and slope coefficients of regression equations, fewer minor differences between the soils were noted for the linear than for non-linear regression.

\subsubsection{Splash Erosion and Mean Rainfall Intensity}

Splash erosion plotted against the $I_{a v}$ (calculated according to Equation (4)), resulted in linear relationships for the three soils (Figure 7). Compared to previous results with $K E_{h}$, most of the data were grouped in the range of low intensities up to $10 \mathrm{~mm} \mathrm{~h}^{-1}$, and the highest $I_{a v}$ corresponds to a $K E_{h}$ of $650 \mathrm{~J} \mathrm{~m}^{-2} \mathrm{~h}^{-1}$. The three extreme measurements from the previous example with $K E_{h}\left(\mathrm{E}_{1-3}\right)$ were more linearly distributed with increasing $I_{a v}$; however, they still deviate from the regression lines (Figure 7a).
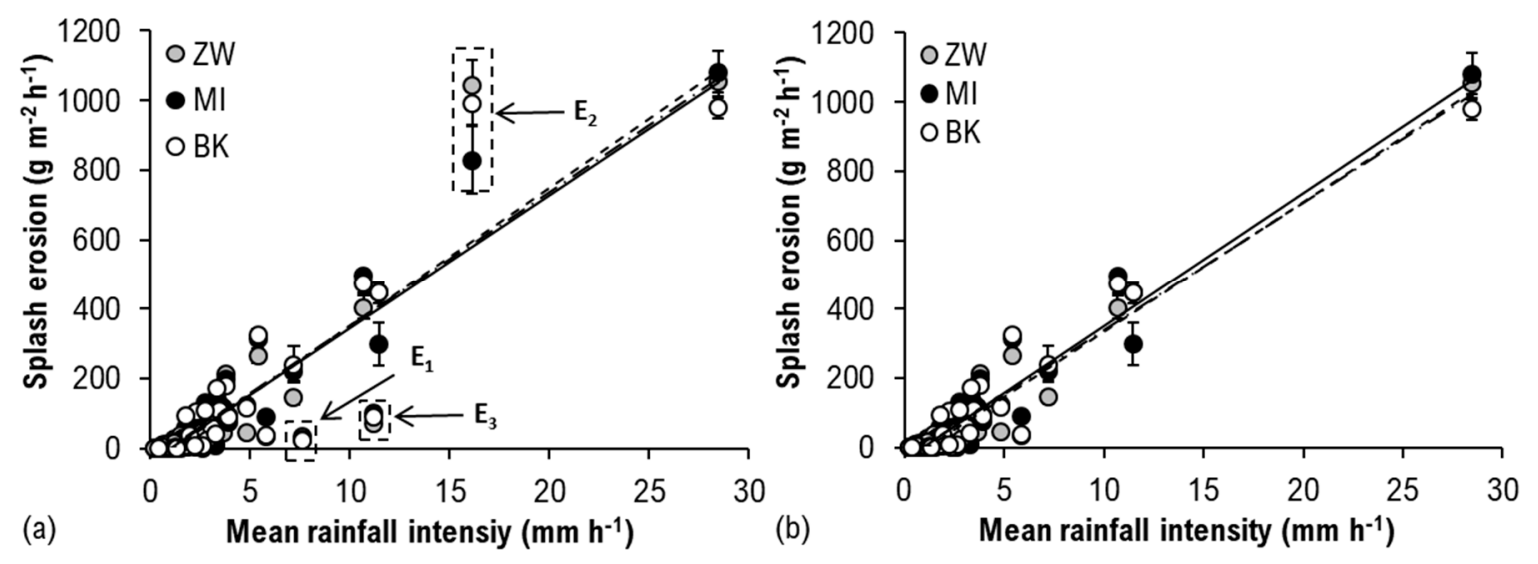

Figure 7. Mean splash erosion for Zwerbach (ZW), Mistelbach (MI), and Bílkovice (BK) soil versus mean rainfall intensity, including (a) all observations $(n=80)$ and $(\mathbf{b})$ without extreme observations $(n=77)$. The dashed line represents the regression function for $\mathrm{ZW}$, as does the solid line for MI and the dashed-dotted line for BK soil. The points inside the dashed boxes indicate extreme observations $\left(\mathrm{E}_{1}, \mathrm{E}_{2}\right.$, and $\left.\mathrm{E}_{3}\right)$ per soil.

The regression analysis without extreme observations did not greatly affect the linear regression for the three soils; nevertheless, $R^{2}$ increased for all soils, with the highest increase from 0.81 to 0.93 calculated for the ZW soil (Table 5).

Table 5. Main outputs of the regression analysis between mean splash erosion $S_{h}\left(\mathrm{~g} \mathrm{~m}^{-2} \mathrm{~h}^{-1}\right)$ for Zwerbach (ZW), Mistelbach (MI), and Bílkovice (BK) soil, and mean rainfall intensity $I_{a v}\left(\mathrm{~mm} \mathrm{~h}^{-1}\right)$. The $R^{2}$ is the determination coefficient of the regression model, and RMSE $\left(\mathrm{g} \mathrm{m}^{-2} \mathrm{~h}^{-1}\right)$ indicates the root mean squared error. $\mathrm{E}_{1}, \mathrm{E}_{2}$, and $\mathrm{E}_{3}$ denote extreme observations.

\begin{tabular}{ccccc}
\hline Parameter & Soil & Equation & $\boldsymbol{R}^{\mathbf{2}}$ & RMSE \\
\hline \multirow{3}{*}{$I_{a v}$ (including $\left.\mathrm{E}_{1}, \mathrm{E}_{2}, \mathrm{E}_{3}\right)$} & $\mathrm{ZW}$ & $S_{h}=39.765 \cdot I_{a v}-47.492$ & 0.81 & 77.08 \\
& $\mathrm{MI}$ & $S_{h}=38.379 \cdot I_{a v}-39.707$ & 0.86 & 62.50 \\
& $\mathrm{BK}$ & $S_{h}=38.578 \cdot I_{a v}-34.877$ & 0.82 & 73.06 \\
\hline & $\mathrm{ZW}$ & $S_{h}=37.658 \cdot I_{a v}-42.101$ & 0.93 & 37.78 \\
$I_{a v}\left(\right.$ excluding $\left.\mathrm{E}_{1}, \mathrm{E}_{2}, \mathrm{E}_{3}\right)$ & $\mathrm{MI}$ & $S_{h}=38.691 \cdot I_{a v}-36.893$ & 0.93 & 37.68 \\
& $\mathrm{BK}$ & $S_{h}=36.960 \cdot I_{a v}-30.124$ & 0.93 & 37.66 \\
\hline
\end{tabular}




\subsubsection{Splash Erosion and Rainfall Erosivity $\left(E I_{30}\right)$}

The relationship between splash erosion and $E I_{30}$ resulted in a non-linear power function (Figure $8 \mathrm{a}$ ), with $R^{2}$ values of 0.60 for $\mathrm{ZW}, 0.64$ for $\mathrm{MI}$, and 0.65 for $\mathrm{BK}$ soil, including the extreme observations (Table 6). Most of the observations were grouped up to an $E_{30}$ value of 250 (MJ ha mm $\mathrm{m}^{-1} \mathrm{~h}^{-1}$ ), with high variations in splash erosion (from 5 to $1586 \mathrm{~g} \mathrm{~m}^{-2}$ ) between the single observations. Minor differences in $R^{2}$ and RMSE between the analysis with and without extreme observations indicated better correlation of extreme splash erosion observations to $E I_{30}$ (Table 6). The highest splash erosion rates were indicated for BK soil, similar to the results obtained with $K E_{\text {sum }}$ seen in Figure 4.
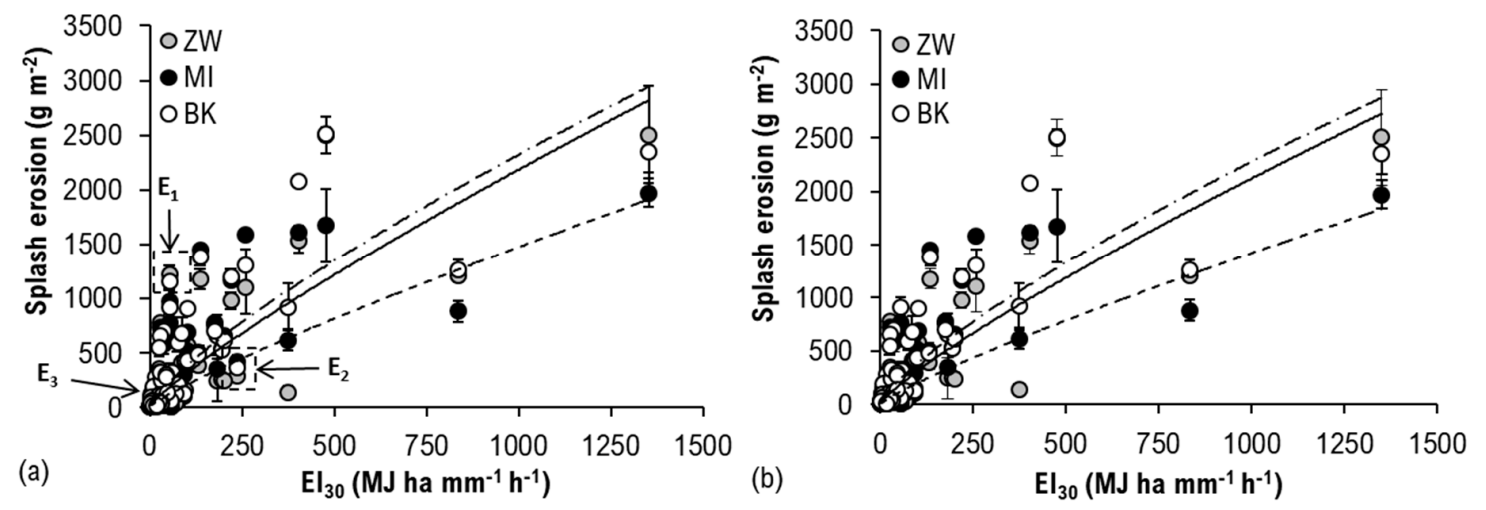

Figure 8. Average splash erosion for Zwerbach (ZW), Mistelbach (MI), and Bílkovice (BK) soil versus mean rainfall erosivity $\left(E I_{30}\right)$, including (a) all observations $(n=80)$ and $(\mathbf{b})$ those without extreme observations $(n=77)$. The dashed line represents regression function for $\mathrm{ZW}$, as does the solid line for MI and the dashed-dotted line for BK soil. The points inside the dashed boxes indicate extreme observations $\left(E_{1}, E_{2}\right.$, and $\left.E_{3}\right)$ per soil.

Table 6. Main outputs of the regression analysis between mean splash erosion $S\left(\mathrm{~g} \mathrm{~m}^{-2}\right)$ for Zwerbach (ZW), Mistelbach (MI), and Bílkovice (BK) soil and rainfall erosivity factor $E I_{30}\left(\mathrm{MJ}\right.$ ha $\left.\mathrm{mm}^{-1} \mathrm{~h}^{-1}\right) . R^{2}$ is the determination coefficient of the regression model, and RMSE $\left(\mathrm{g} \mathrm{m}^{-2}\right)$ indicates the root mean squared error. $E_{1}, E_{2}$, and $E_{3}$ denote extreme observations.

\begin{tabular}{ccccc}
\hline Parameter & Soil & Equation & $\boldsymbol{R}^{\mathbf{2}}$ & RMSE \\
\hline \multirow{2}{*}{$E I_{30}$ (including $\left.\mathrm{E}_{1}, \mathrm{E}_{2}, \mathrm{E}_{3}\right)$} & $\mathrm{ZW}$ & $S=3.927 \cdot E I_{30} 0.858$ & 0.60 & 335.23 \\
& $\mathrm{MI}$ & $S=6.418 \cdot E I_{30} 0.844$ & 0.64 & 299.95 \\
& $\mathrm{BK}$ & $S=10.233 \cdot E I_{30} 0.785$ & 0.65 & 310.70 \\
\hline \multirow{2}{*}{$E I_{30}$ (excluding $\left.\mathrm{E}_{1}, \mathrm{E}_{2}, \mathrm{E}_{3}\right)$} & $\mathrm{ZW}$ & $S=3.899 \cdot E I_{30} 0.854$ & 0.60 & 322.87 \\
& $\mathrm{MI}$ & $S=6.572 \cdot E I_{30} 0.836$ & 0.65 & 287.67 \\
& $\mathrm{BK}$ & $S=10.517 \cdot E I_{30} 0.778$ & 0.65 & 294.55 \\
\hline
\end{tabular}

\section{Discussion}

Comparable studies to our splash erosion experiments under natural rainfall were made in Portugal by Fernández-Raga et al. [42], and in Spain by Angulo-Martínez et al. [43]. The Thies disdrometer was used in both studies to directly assess rainfall $K E$. The splash erosion rates measured by Fernández-Raga et al. [42] were between 2.3 and $100 \mathrm{~g} \mathrm{~m}^{-2}$. In the same range of total $K E$ measured at our sites, splash erosion for loamy sand soil, which was most similar to the texture from the study in Portugal, was between 12 and $2508 \mathrm{~g} \mathrm{~m}^{-2}$. However, the Portugal study was based on only nine splash erosion records, during which low rainfall intensities characterized by small raindrops $(<0.55 \mathrm{~mm})$ were measured. According to findings by Bubenzer and Jones [59], smaller drops produce significantly less splash erosion than larger ones, even for the same amount of $K E$. This would explain the lower splash erosion rates compared to our measurements, where more erosive rainfall events with larger mean 
drop sizes $(>0.6 \mathrm{~mm})$ were measured. Furthermore, differences in splash erosion measuring principles could also play a role when comparing results. In Portugal, the cup was placed directly on the soil bed, and splashed particles were collected from the surrounding soil. We prepared the soil samples and measured the particles splashed into the collector surrounding the soil. Fernández-Raga et al. [42] described splash erosion as the linear function of total $K E$, with the $R^{2}$ being 0.51 and 0.69 for different drop size and intensities thresholds used. That corresponds with our observations for the loamy sand soil, where an $R^{2}$ of 0.52 was obtained.

The study from Angulo-Martínez et al. [43] was more comparable to ours, considering that the Morgan splash cups were used for the splash erosion measurements. However, the samples were kept undisturbed during the whole monitoring period, whereas our samples were exchanged after each rainfall event. Splash erosion was measured for three soils with silt, sandy loam, and clay loam textures. The authors suggested $E I_{30}$ as a controlling factor for splash erosion where no differences in detached rates between the soils were reported. Comparable splash erosion rates from our analysis with $E I_{30}$ were found up to $200 \mathrm{MJ}$ ha $\mathrm{mm}^{-1} \mathrm{~h}^{-1}$; however, with increasing $E I_{30}$, our splash erosion rates increased up to $2500 \mathrm{~g} \mathrm{~m}^{-2}$, whereas the rates from Spain remained constant with an average rate of $337 \mathrm{~g} \mathrm{~m}^{-2}$. The fact that the samples were exchanged between measurements may contribute to higher rates obtained for soils in our study, which was in seedbed conditions.

There is still no general agreement on which rainfall parameters define splash erosion [12]. Parameters dependent on raindrop size and fall velocity, such as rainfall $K E$, momentum, intensity, or a combination of these, are commonly used to describe the raindrop impact on splash detachment. According to our analysis, $K E_{\text {sum }}$ could not (Figure 4) explain the variabilities between splash erosion rates obtained for the same amount of $K E$. The reason for that lies in different rainfall intensities between the rainfall events, where high-intensity rainfall produced more splash erosion than low-intensity rainfall (Figure 5). In the field study by Govers [36], it was also concluded that the use of KE as an estimate of the rainfall detachment power leads to an underestimation of the relative impact of events with high intensities. From the strong linear relationship between splash erosion and rainfall intensity obtained in our study (Figure 7, Table 5), it can be stated that the splash erosion was more related to rainfall intensity than to other analyzed parameters $\left(K E_{\text {sum }}, K E_{h}\right.$ and $\left.E I_{30}\right)$. Nevertheless, we found good agreement between the splash erosion and $K E_{\text {sum }}$ divided by rainfall duration ( $T$ ) (Figure 6, Table 4). This indicates that $K E$ can also be used as the parameter to predict splash erosion, even when events with different rainfall intensities are analyzed, but its erosive impact has to be expressed through rainfall duration.

The detailed information about drop size distribution allowed us to discern the differences in rainfall characteristics between the study sites. The differences in the splash rates between the rainfall events for the same range of $K E$ also contributed to the differing drop size distribution. This was also noticed for the splash rates measured at the Mistelbach site, which is characterized as the site with the highest average raindrop diameter. Another example of this is the extreme event $\left(E_{2}\right)$ reported in the results (Figure 6), where the high splash erosion rates were affected by the large drop size measured for this event. Bubenzer and Jones [59] found that rainfall with larger drops produce more detachment than rainfall with smaller drops, for rainfall having the same total KE. Recently, Fu et al. [60] also reported the gradual increase of splash erosion rates with increasing raindrop diameter. Detailed information about raindrop size distribution plays an important role for splash erosion studies like ours, where the direct measurements of the parameters is needed to describe the factors affecting the splash erosion process.

The soil's physical characteristics (texture, soil moisture, organic matter, structure, infiltration capacity, etc.) play an important role in understanding the soil detachment by raindrop splash [2]. Splash erosion of the three soils was positively correlated to the sand content, and significantly $(p<0.05)$ negatively correlated to clay content. For this reason, cumulative splash erosion rates were highest for the BK soil with highest sand content, and significantly different $(p<0.05)$ from ZW soil with the highest clay content (Table 1). Equivalent results were reported in a recent study by Zambon et al. [61], 
using simulated rainfall on same soils. The high splash detachability of soils with dominating sand content was also confirmed in experiments by Salles et al. [3], Cheng et al. [19], and Xiao et al. [62]. However, the results of the regression and correlation analysis between splash erosion per rainfall duration and $K E_{h}$, as well as $I_{a v}$, indicates small differences between the three soils. Other soil properties, such as soil moisture, also have a significant impact on splash erosion $[17,63,64]$. The results reported by Zambon et al. [61] show that lower splash erosion rates are related to high initial soil water content, followed by surface ponding and changes in saturated hydraulic conductivity induced by surface crusting under high rainfall intensities. Although it was not possible to monitor the changes in soil moisture and surface conditions in the field, these effects probably contributed to results obtained in this field study, especially for the extreme observation $\mathrm{E}_{3}$. During this observation, two rainfall sub-events were recorded. The second major rainfall sub-event (with total rainfall of $40 \mathrm{~mm}$ ) occurred $48 \mathrm{~h}$ later. Therefore, low splash erosion rates could be related to the long drying period between the first and second rainfall-sub event, resulting in increasing soil surface resistance against the raindrop impact [65]. A more detailed study, including the temporal monitoring of surface changes and soil moisture properties, would possibly contribute to clarifying the complex interaction between soil properties and rainfall controlling the splash erosion process.

Apart from the differences in the rainfall characteristic and soil properties, the experimental design for splash erosion assessment plays an important role when comparing the results from different studies. Recently, a study was published by Fernández-Raga et al. [25] that compared different devices for splash erosion measurements, where the results were strongly affected by the measurement device. This was also visible when comparing our results to the above-described studies. However, low standard deviations between the replicates for each soil obtained in our study confirm that the modified version of the Morgan splash cup provided reliable results for splash erosion measurements.

\section{Conclusions}

This study analyzed the effect of rainfall parameters on splash erosion under natural rainfall on three sites in Central Europe. Based on the results obtained during the three seasons of measurements, we conclude that splash erosion is more dependent on rainfall intensity than on total kinetic energy and rainfall erosivity $\left(E I_{30}\right)$. Still, the kinetic energy of a natural rainfall event can be used as suitable erosivity parameter when dividing it by the rainfall duration. Monitoring of rainfall properties (intensity and kinetic energy) is important to discern the spatial and temporal differences in rainfall characteristics, which influence splash erosion. The dynamic changes in soil moisture, infiltration capacity, and surface roughness affected by weather conditions can lead to uncertainties in the evaluation of splash erosion in the field. Minor differences between the replicates during splash erosion measurements indicate that the modified Morgan splash cup provides a good tool for soil erosion assessment.

Author Contributions: Conceptualization, N.Z. and A.K.; methodology, A.K., T.D., D.Z., T.A.C. and P.S.; formal analysis, N.Z.; investigation, N.Z., L.L.J., and M.N.; resources, P.S., T.D., and A.K.; writing-original draft preparation, N.Z.; writing - review and editing, all authors; visualization, N.Z.; supervision, P.S., T.D., T.A.C. and A.K.; project administration, T.D. and A.K.; funding acquisition, P.S., T.D., and A.K. All authors have read and agreed to the published version of the manuscript.

Funding: This research was performed within the project "Kinetic energy of rainfall as a driving force of soil detachment and transport". Financial support was provided through the Austrian Science Fund (FWF): I $3049-$ N29 and the Czech Science Foundation (GACR): GF17-33751L. Open access funding was provided by the Austrian Science Fund (FWF).

Acknowledgments: We want to thank the Technical University in Vienna for providing the data from PWS100 and their vehicle during the field campaign in Petzenkirchen (HOAL). Special thanks to Wolfgang Sokol for data processing support, as well as Franz Aigner and other technical and lab personnel for the support during the project.

Conflicts of Interest: The authors declare no conflict of interest. 


\section{References}

1. Montgomery, D.R. Soil erosion and agricultural sustainability. Proc. Natl. Acad. Sci. USA 2007, 104, 13268-13272. [CrossRef] [PubMed]

2. Fernández-Raga, M.; Palencia, C.; Keesstra, S.; Jordán, A.; Fraile, R.; Angulo-Martínez, M.; Cerdà, A. Splash erosion: A review with unanswered questions. Earth Sci. Rev. 2017, 171, 463-477. [CrossRef]

3. Salles, C.; Poesen, J.; Govers, G. Statistical and physical analysis of soil detachment by raindrop impact: Rain erosivity indices and threshold energy. Water Resour. Res. 2000, 36, 2721-2729. [CrossRef]

4. Morgan, R.P.C. Soil Erosion and Conservation, 3rd ed.; Blackwell Publishing Company: Oxford, UK, 2005.

5. Smith, D.D.; Wischmeier, W. Factors affecting sheet and rill erosion. Trans. Am. Geophys. Union 1957, 38, 889-896. [CrossRef]

6. Rose, C.; Williams, J.; Sander, G.; Barry, D. A Mathematical Model of Soil Erosion and Deposition Processes: I. Theory for a Plane Land Element1. Soil Sci. Soc. Am. J. 1983, 47, 991-995. [CrossRef]

7. Nearing, M.; Foster, G.R.; Lane, L.J.; Finkner, S.C. A Process-Based Soil Erosion Model for USDA-Water Erosion Prediction Project Technology. Trans. ASAE 1989, 32, 1587. [CrossRef]

8. Wischmeier, W.H.; Smith, D. Rainfall energy and its relationship to soil loss. Trans. Am. Geophys. Union 1958, 39, 285-291. [CrossRef]

9. Poesen, J. An improved splash transport model. Z. Geomorphol. 1985, 29, 193-211.

10. Morgan, R.P.C.; Quinton, J.N.; Smith, R.E.; Govers, G.; Poesen, J.W.A.; Auerswald, K.; Chisci, G.; Torri, D.; Styczen, M.E.; Folly, A.J. The European Soil Erosion Model (EUROSEM): Documentation and User Guide; Cranfield University: Silsoe, UK, 1998.

11. Renard, K.G.; Foster, G.R.; Weesies, G.A.; McCool, D.K.; Yoder, D.C. Predicting Soil Erosion by Water: A Guide to Conservation Planning With the Revised Universial Soil Erosion Equation (RUSLE); US Derpartment of Agriculture: Washington, DC, USA, 1997.

12. Salles, C.; Poesen, J. Rain properties controlling soil splash detachment. Hydrol. Process. 2000, 14, $271-282$. [CrossRef]

13. Assouline, S. Infiltration into soils: Conceptual approaches and solutions. Water Resour. Res. 2013, 49, 1755-1772.

14. Wang, G.; Fang, Q.; Wu, B.; Yang, H.; Xu, Z. Relationship between soil erodibility and modeled infiltration rate in different soils. J. Hydrol. 2015, 528, 408-418. [CrossRef]

15. Liu, H.; Lei, T.W.; Zhao, J.; Yuan, C.P.; Fan, Y.T.; Qu, L.Q. Effects of rainfall intensity and antecedent soil water content on soil infiltrability under rainfall conditions using the run off-on-out method. J. Hydrol. 2011, 396, 24-32. [CrossRef]

16. Beczek, M.; Ryżak, M.; Sochan, A.; Mazur, R.; Bieganowski, A. The mass ratio of splashed particles during raindrop splash phenomenon on soil surface. Geoderma 2019. [CrossRef]

17. Le Bissonnais, Y.; Renaux, B.; Delouche, H. Interactions between soil properties and moisture content in crust formation, runoff and interrill erosion from tilled loess soils. Catena 1995, 25, 33-46. [CrossRef]

18. Le Bissonnais, Y. Aggregate stability and assessment of soil crustability and erodibility: I. Theory and methodology. Eur. J. Soil Sci. 2016, 67, 11-21. [CrossRef]

19. Cheng, Q.; Cai, Q.; Ma, W. Comparative study on rain splash erosion of representative soils in China. Chin. Geogr. Sci. 2008, 18, 155-161. [CrossRef]

20. Beguería, S.; Angulo-Martínez, M.; Gaspar, L.; Navas, A. Detachment of soil organic carbon by rainfall splash: Experimental assessment on three agricultural soils of Spain. Geoderma 2015, 245, 21-30. [CrossRef]

21. Torri, D.; Poesen, J. The effect of cup size on splash detachment and transport measurements. Part II: Theoretical approach. Catena Suppl. 1988, 12, 113-126.

22. Ellison, W.D. Studies of raindrop erosion. Agric. Eng. 1944, 25, 131-136.

23. Morgan, R.P.C. Field measurement of splash erosion (Bedfordshire, England). Eros. Sediment. Transp. Meas. Proc. Florence Symp. (Int. Assoc. Hydrol. Sci. IAHS-AISH) 1981, 133, 373-382.

24. Ma, B.; Liu, Y.; Liu, X.; Ma, F.; Wu, F.; Li, Z. Soil splash detachment and its spatial distribution under corn and soybean cover. Catena 2015, 127, 142-151. [CrossRef]

25. Fernández-Raga, M.; Campo, J.; Rodrigo-Comino, J.; Keesstra, S.D. Comparative analysis of splash erosion devices for rainfall simulation experiments: A laboratory study. Water (Switzerland) 2019, 11, 1-21. [CrossRef] 
26. Scholten, T.; Geißler, C.; Goc, J.; Kühn, P.; Wiegand, C. A new splash cup to measure the kinetic energy of rainfall. J. Plant. Nutr. Soil Sci. 2011, 174, 596-601. [CrossRef]

27. Quansah, C. The effect of soil type, slope, rain intensity and their interactions on splash detachment and transport. J. Soil Sci. 1981, 32, 215-224. [CrossRef]

28. Kinnell, P.I.A. Laboratory studies on the effect of drop size on splash erosion. J. Agric. Eng. Res. 1982, 27, 431-439. [CrossRef]

29. Sharma, P.P.; Gupta, S.C. Sand Detachment by Single Raindrops of Varying Kinetic Energy and Momentum. Soil Sci. Soc. Am. J. 1989, 53, 1005-1010. [CrossRef]

30. Fu, Y.; Li, G.; Wang, D.; Zheng, T.; Yang, M. Raindrop energy impact on the distribution characteristics of splash aggregates of cultivated dark loessial cores. Water (Switzerland) 2019, 11, 1514. [CrossRef]

31. Van Dijk, A.I.J.M.; Bruijnzeel, L.A.; Eisma, E.H. A methodology to study rain splash and wash processes under natural rainfall. Hydrol. Process. 2003, 17, 153-167. [CrossRef]

32. Iserloh, T.; Ries, J.B.; Arnáez, J.; Boix-Fayos, C.; Butzen, V.; Cerdà, A.; Echeverría, M.T.; Fernández-Gálvez, J.; Fister, W.; Geißler, C.; et al. European small portable rainfall simulators: A comparison of rainfall characteristics. Catena 2013. [CrossRef]

33. Lassu, T.; Seeger, M.; Peters, P.; Keesstra, S.D. The Wageningen Rainfall Simulator: Set-up and Calibration of an Indoor Nozzle-Type Rainfall Simulator for Soil Erosion Studies. Land Degrad. Dev. 2015, 26, 604-612. [CrossRef]

34. Morgan, R.P.C. Splash detachment under plant covers: results and implications of a field study. Trans. Am. Soc. Agric. Eng. 1982, 25, 987-991. [CrossRef]

35. Hudson, N.W. The Influence of Rainfall on the Mechanics of Soil Erosion: With Particular Reference to Southern Rhodesia. Master's Thesis, University of Cape Town, Cape Town, South Africa, 1965.

36. Govers, G. Spatial and temporal variations in splash detachment: a field study. Catena Suppl. 1991, $20,15-24$.

37. Laws, J.O. Measurements of the fall-velocity of water -drops and raindrops. Trans. Am. Geophys. Union 1941, 22, 709. [CrossRef]

38. van Dijk, A.I.J.M.; Bruijnzeel, L.A.; Rosewell, C.J. Rainfall intensity-Kinetic energy relationships: A critical literature appraisal. J. Hydrol. 2002, 261, 1-23. [CrossRef]

39. Dunkerley, D. Rain event properties in nature and in rainfall simulation experiments: A comparative review with recommendations for increasingly systematic study and reporting. Hydrol. Process. 2008, 22, 4415-4435. [CrossRef]

40. Johannsen, L.L.; Zambon, N.; Strauss, P.; Dostal, T.; Neumann, M.; Zumr, D.; Cochrane, T.A.; Klik, A. Impact of Disdrometer Types on Rainfall Erosivity Estimation. Water 2020, 12, 963. [CrossRef]

41. Kinnell, P.I.A. Problem of Assessing the Erosive Power of Rainfall from Meteorological Observations. Soil Sci. Soc. Am. Proc. 1973, 37, 617-621. [CrossRef]

42. Fernández-Raga, M.; Fraile, R.; Keizer, J.J.; Varela Teijeiro, M.E.; Castro, A.; Palencia, C.; Calvo, A.I.; Koenders, J.; Da Costa Marques, R.L. The kinetic energy of rain measured with an optical disdrometer: An application to splash erosion. Atmos. Res. 2010, 96, 225-240. [CrossRef]

43. Angulo-Martínez, M.; Beguería, S.; Navas, A.; Machín, J. Splash erosion under natural rainfall on three soil types in NE Spain. Geomorphology 2012, 175-176, 38-44. [CrossRef]

44. Bauer, B. Soil splash as an important agent of erosion. Geogr. Pol. 1990, 58, 99-106.

45. Land Niederösterreich. Wasserstandsnachrichten und Hochwasserprognosen. Messstellendaten. Wieselburg. Available online: https://www.noe.gv.at/wasserstand/\#/de/Messstellen/Details/107235/Niederschlag/3Tage (accessed on 25 November 2019).

46. Land Niederösterreich. Wasserstandsnachrichten und Hochwasserprognosen. Messstellendaten. Mistelbach. Available online: https://www.noe.gv.at/wasserstand/\#/de/Messstellen/Details/99116541/Niederschlag/3Tage (accessed on 25 November 2019).

47. Czech Hydrometeorological Institute. Prague Clementinum: Basic Data on Prague Clementinum Station. Available online: http://portal.chmi.cz/historicka-data/pocasi/praha-klementinum?l=en\# (accessed on 25 November 2019).

48. Klik, A.; Truman, C.C. What is a Typical Heavy Rainstorm? In Proceedings of the 25 Years of Assesment of Erosion, Proceedings of International Symposium, Ghent, Belgium, 22-26 September 2003; Gabriels, D., Cornelis, W., Eds.; Ghent University: Ghent, Belgium, 2003; pp. 93-98. 
49. Panagos, P.; Borrelli, P.; Spinoni, J.; Ballabio, C.; Meusburger, K.; Beguería, S.; Klik, A.; Michaelides, S.; Petan, S.; Hrabalíková, M.; et al. Monthly rainfall erosivity: Conversion factors for different time resolutions and regional assessments. Water (Switzerland) 2016, 8, 119. [CrossRef]

50. ÖNORM L1061-1. Physikalische Bodenuntersuchungen-Bestimmung der Korngrößenverteilung des Mineralbodens; Teil 1; Grobboden, Austrian Standards Institute: Vienna, Austria, 2002.

51. ÖNORM L1061-2. Physikalische Bodenuntersuchungen-Bestimmung der Korngrößenverteilung des Mineralbodens; Teil 2; Feinboden, Austrian Standards Institute: Vienna, Austria, 2002.

52. ÖNORM L 1050. Boden als Pflanzenstandort-Begriffsbestimmungen, Untersuchungsverfahren; Austrian Standards Institute: Vienna, Austria, 1994.

53. ÖNORM L 1080. Chemische Bodenuntersuchungen-Bestimmung des organischen Kohlenstoffs durch trockene Verbrennung mit und ohne Berücksichtigung von Carbonaten; Austrian Standards Institute: Vienna, Austria, 1987.

54. Kemper, W.D.; Rosenau, R.C. Aggregate Stability and Size Dlstributlon. In Methods of soil analysis: Part 1 Physical and Mineralogical Methods; Klute, A., Ed.; American Society of Agronomy—Soil Science Socity of America: Madison, WI, USA, 1986; pp. 425-442.

55. Zumr, D.; Mützenberg, D.V.; Neumann, M.; Jeřábek, J.; Laburda, T.; Kavka, P.; Johannsen, L.L.; Zambon, N.; Klik, A.; Strauss, P.; et al. Experimental Setup for Splash Erosion Monitoring-Study of Silty Loam Splash Characteristics. Sustainability 2019, 12, 157. [CrossRef]

56. Richter, G.; Negendank, J.F.W. Soil erosion processes and their measurement in the german area of the Moselle river. Earth Surf. Process. 1977, 2, 261-278. [CrossRef]

57. Johannsen, L.L.; Zambon, N.; Strauss, P.; Dostal, T.; Neumann, M.; Zumr, D.; Cochrane, T.A.; Blöschl, G.; Klik, A. Comparison of three types of laser optical disdrometers under natural rainfall conditions. Hydrol. Sci. J. 2020, 65, 524-535. [CrossRef]

58. Kruskal, W.H.; Wallis, W.A. Use of Ranks in One-Criterion Variance Analysis. J. Am. Stat. Assoc. 1952, 47, 583-621. [CrossRef]

59. Bubenzer, G.D.; Jones, B. Drop size and impact velocity effects on the detachment of soils under simulated rainfall. Trans. Am. Soc. Agric. Eng. 1971, 14, 625-628. [CrossRef]

60. Fu, Y.; Li, G.; Zheng, T.; Li, B.; Zhang, T. Splash detachment and transport of loess aggregate fragments by raindrop action. Catena 2017, 150, 154-160. [CrossRef]

61. Zambon, N.; Johannsen, L.L.; Strauss, P.; Dostál, T.; Zumr, D.; Cochrane, T.A.; Klik, A. Splash erosion affected by initial soil moisture and surface conditions under simulated rainfall. Catena. under review.

62. Xiao, H.; Liu, G.; Zhang, Q.; Fenli, Z.; Zhang, X.; Liu, P.; Zhang, J.; Hu, F.; Elbasit, M.A.M.A. Quantifying contributions of slaking and mechanical breakdown of soil aggregates to splash erosion for different soils from the Loess plateau of China. Soil Tillage Res. 2018, 178, 150-158. [CrossRef]

63. Ryzak, M.; Bieganowski, A.; Polakowski, C. Effect of soil moisture content on the splash phenomenon reproducibility. PLoS ONE 2015, 10, 1-15. [CrossRef]

64. Assouline, S.; Mualem, Y. Modeling the dynamics of seal formation and its effect on infiltration as related to soil and rainfall characteristics. Water Resour. Res. 1997, 33, 1527-1536. [CrossRef]

65. Caron, J.; Kay, B.D.; Stone, J.A. Improvement of Structural Stability of a Clay Loam with Drying. Soil Sci. Soc. Am. J. 1992, 56, 1583-1590. [CrossRef]

(C) 2020 by the authors. Licensee MDPI, Basel, Switzerland. This article is an open access article distributed under the terms and conditions of the Creative Commons Attribution (CC BY) license (http://creativecommons.org/licenses/by/4.0/). 